Sado Marine Biological Station (Dr. Y. Honma), ${ }^{1}$ Faculty of Science, Niigata University, and Department of Oral Anatomy, ${ }^{2}$ Nippon Dental College, Niigata; and Anatomy Section, ${ }^{3}$ Institute of Basic Medicine,

University of Tsukuba, Ibaraki-ken, Japan

\title{
Scanning Electron Microscopy of the Third Ventricular Wall in the Lamprey, Lampetra japonica*
}

\author{
Seiji Shioda, Yoshiharu Honma, ${ }^{1}$ Sumio Yoshie $^{2}$ \\ and \\ Yasuhiko Hosoy ${ }^{3}$
}

Received October 26, 1976

\begin{abstract}
Summary. The third ventricular wall and its adjacent region of the arctic lamprey, Lampetra japonica, were studied by scanning electron microscopy to elucidate their surface fine structures. The specimens were caught in the mouth of the river during their anadromous migration.

The ventricular wall is covered entirely with the cilia of ependymal cells, with the exception of the ventral side of the lateral wall, the floor of the recessus infundibuli and a portion of the recessus posteriosus. In the ependymal layer covering the ventral side of the lateral wall, numerous protrusions of neurons are found equipped with microvilli and cilia. These neurons seem to correspond to the liquor-contacting neurons. Ependymal cells identified as tanycytes occur in the posterior portion of the floor of the recessus infundibuli. The apex of the tanycyte is provided with numerous microvilli and a bundle of cilia, while its basal projection extends towards the outer layer of neurohypophysis to make contact with the capillary wall. A small spherule considered to be a secretory substance is observed near the root of the ciliary bundle. The recessus posteriosus consists of a layer of ependymal cells and neurons with an apical projection into the ventricular cavity. Possible intraventricular macrophage (Kolmer cell) is found in the lamprey.
\end{abstract}

In the ventricular wall of the higher vertebrates, the ependymal cells and neurons adjacent to the ependyma may be gathered into a circumventricular system and may participate in certain functions. As these neurons are protruded into the ventricular cavity and in direct contact with the cerebrospinal fluid, the term "liquorcontacting neuron" was proposed by VIGH et al. (1960). These structures were demonstrated successively in every vertebrate class, with the exception of the cyclostome as the representative of the most primitive vertebrates (BERTLER et al., 1963; VIGHTeichmann et al., 1970; Vigh, 1971; Clementi and Merini, 1972; DE W Aele et al., 1974).

From the phylogenetic point of view, we have tried to examine the occurrence of monoaminergic neurons in the central nervous system including the hypothalamus of the arctic lamprey (Honma and Honma, 1970; Honma, 1970). In the course of the study, fluorescence appearing as a flame-bulb was demonstrated in the circumventricular area. Encouraged by this finding, the present study was undertaken to demonstrate a neural or humoral pathway between the ventricular area and the hypothalamo-hypophyseal complex in the lamprey. Thus, histological observation was made on the wall of the third ventricle as a portion of the so-called circumventricular system through the central canal of the spinal cord, using scanning electron microscopy, in addition to routine light microscopy.

\footnotetext{
* Contributions from the Sado Marine Biological Station, Niigata University, No. 274.
} 


\section{Material and Methods}

A number of the arctic lamprey, Lampetra japonica, from the Japan Sea in the process of upstream migration for spawning were caught in the lower reaches of the Agano River and the Shinano River during the winter season. After decapitation, blocks of the brain with the area of the third ventricle were removed quickly, and immersed in 5\% glutaraldehyde in cacodylate buffer of $\mathrm{pH}$ 7.4. After washing in cold buffer solution, the material was postfixed with $1 \%$ buffered $\mathrm{OsO}_{4}$ at $4^{\circ} \mathrm{C}$ for 2 hrs. Blocks were dehydrated in ethanol or acetone, transferred to isoamyl acetate and critical-point dried using liquid $\mathrm{CO}_{2}$. The blocks were then coated with carbon and gold and observed and photographed in a JSM-U3 type scanning electron microscope under the accelerating voltage of $10-15 \mathrm{kV}$. For non-coated scanning electron microscope specimens, the tannin-osmium method recommended by MuraKami (1974) was used.

In parallel with scanning electron microscopy, light microscopy was also achieved. The brain was immersed in Bouin-Holland-sublimate solution for 2 days, dehydrated by a series of methanol, embedded in paraplast, cut serially 5 to $6 \mu$ thick in sagittal and transverse directions, and stained chiefly by $\mathrm{PbH}$, and $\mathrm{PAS}-$ alcian blue and orange G (EL ETreby et al., 1973), and observed by a Leitz Orthoplan microscope.

\section{Results}

\section{Light microscopy}

The general structural pattern of the hypothalamo-hypophysial system of the arctic lamprey has already been described by us (Honma, 1969; Honma and Honma, 1970). As shown in low power scanning electron microscopy, the third ventricle is spacious and cylindrical, though the infundibular floor forms the swollen recessus that is lined with the anterior and posterior neurohypophyses (Fig. 1). The present observation covers the dorsal and ventral wall of the third ventricle, i.e., the ventral side of the thalamus and hypothalamus, recessus posteriosus and recessus infundibuli.

By preparation stained with $\mathrm{PbH}$ in combination with $\mathrm{PAS}$ reaction, the neuron with bulbous protrusion is seldom demonstrated in the ependymal layer of the ventral side of lateral wall, the free surface of which is covered with cilia (Fig. 2). In the posterior portion of the floor of the recessus infundibuli, two types of cells can be distinguished besides the predominant ependymal cells: the subependymal cell with an apical tuft, and the bipolar neuron located in the deeper zone (Fig. 3).

\section{Scanning electron microscopy}

Dorsal wall: Most of the surface of the ependymal layer of the third ventricle is covered by numerous cilia. However there is no definite direction in the inclination and bending of the cilia (Fig. 4). Similarly, the major part of the lateral wall of the third ventricle is covered with the cilia projected from the ependymal cell.

Ventral wall (Ventral side of the lateral wall): The lining wall of the ependyma of this region is equipped with dense microvilli and numerous cilia projecting into the ventricular cavity. Large bulbs, tending to be gathered, are protruded from the ependymal surface to the ventricular cavity. They are distributed fairly densely, 


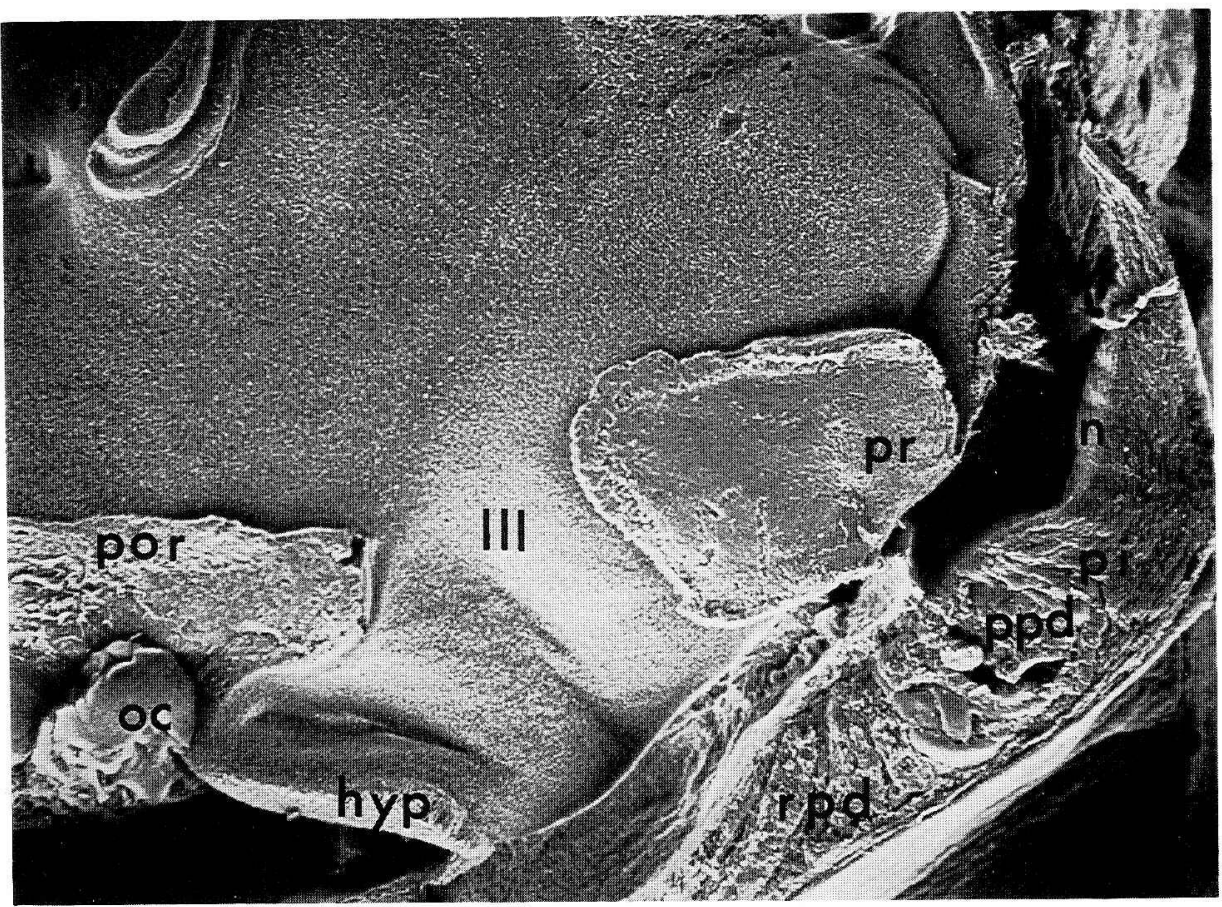

Fig. 1. A low-power scanning electron micrograph (SEM) of a cut surface of the third ventricular area and hypophysis in an adult arctic lamprey, Lampetra japonica. III third ventricle, hyp hypothalamus, oc optic chiasma, por recessus preopticus, $p r$ recessus posteriosus, $n$ neurohypophysis, $r p d$ rostral pars distalis, $p p d$ proximal pars distalis, $p i$ pars intermedia, $\quad \times 40$
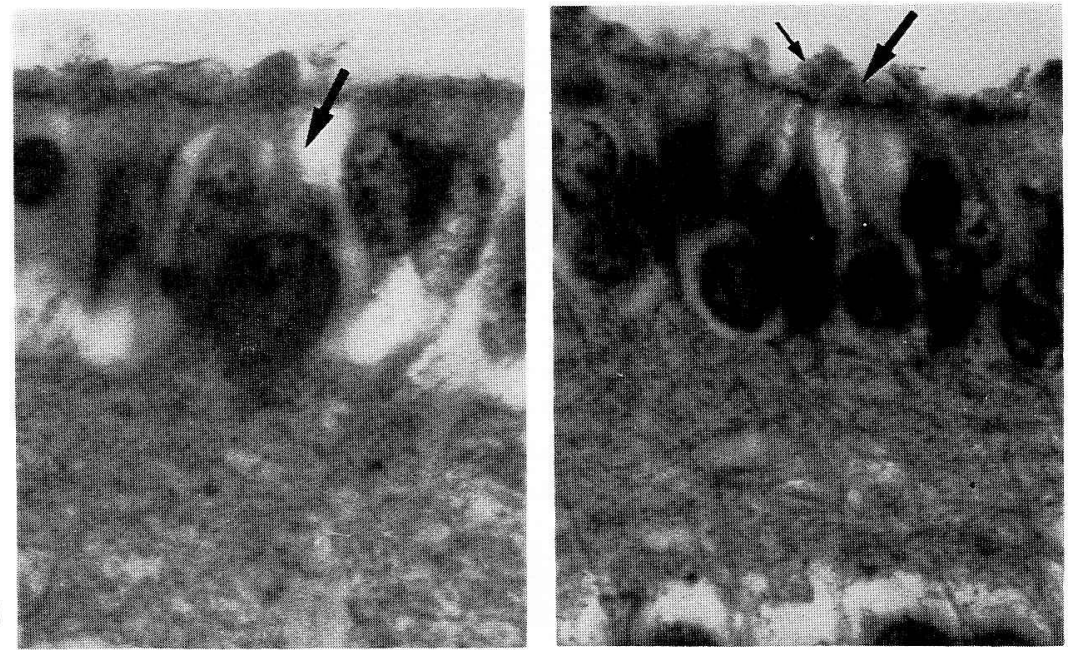

Fig. 2. Section of a part of the ventro-lateral wall in the third ventricle. Cell with bulbous projection referable to the liquor contacting neuron (arrow) is seen. $\mathrm{PbH}$ stain. $\times 1,600$

Fig. 3. A part of the recessus posteriosus showing the bipolar neurons (thick arrow) located in the subependymal layer. The cell with an apical tuft (thin arrow) may be diagnosed as a tanycyte. PbH-PAS stain, $\quad \times 1,600$ 


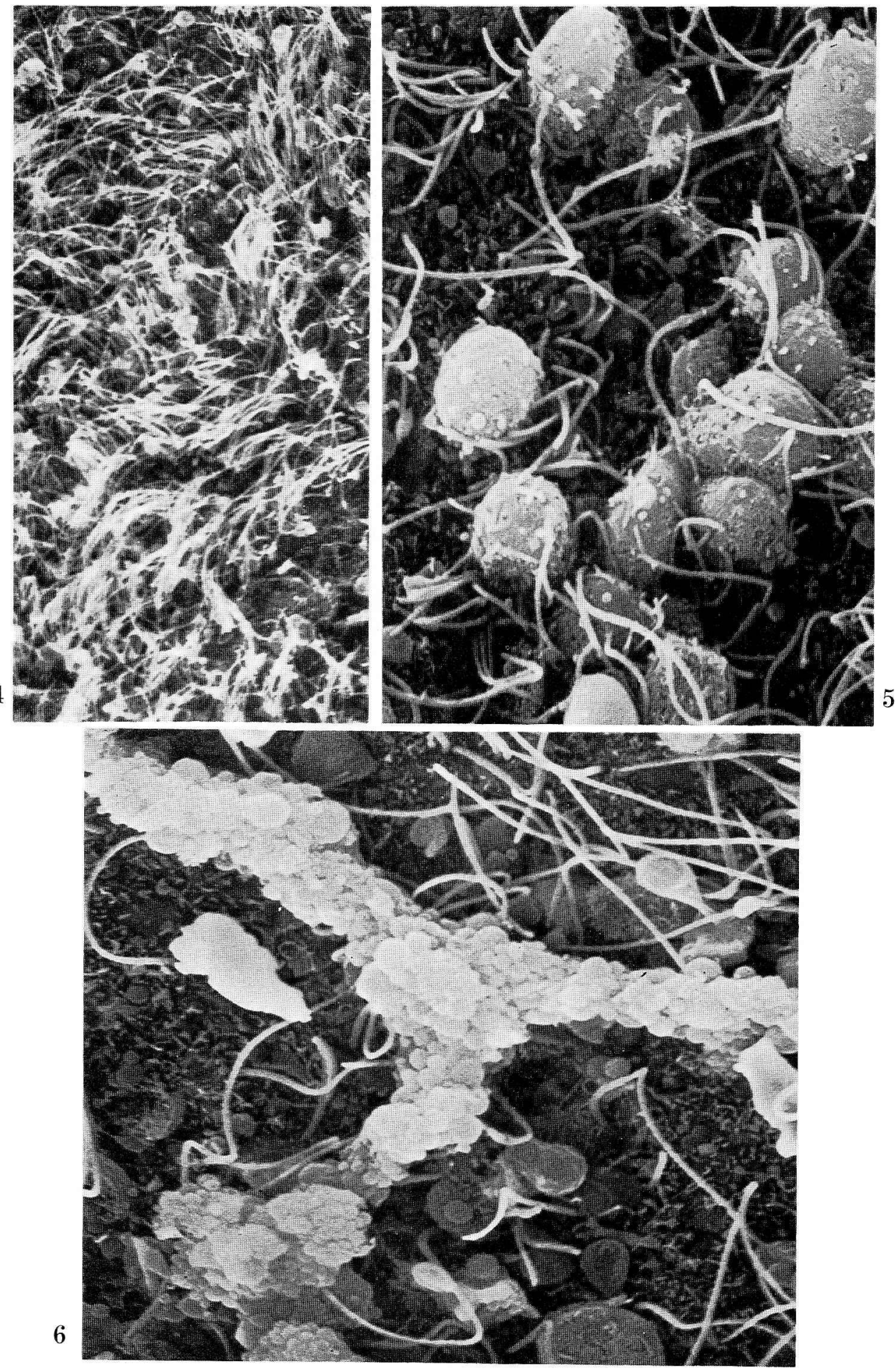




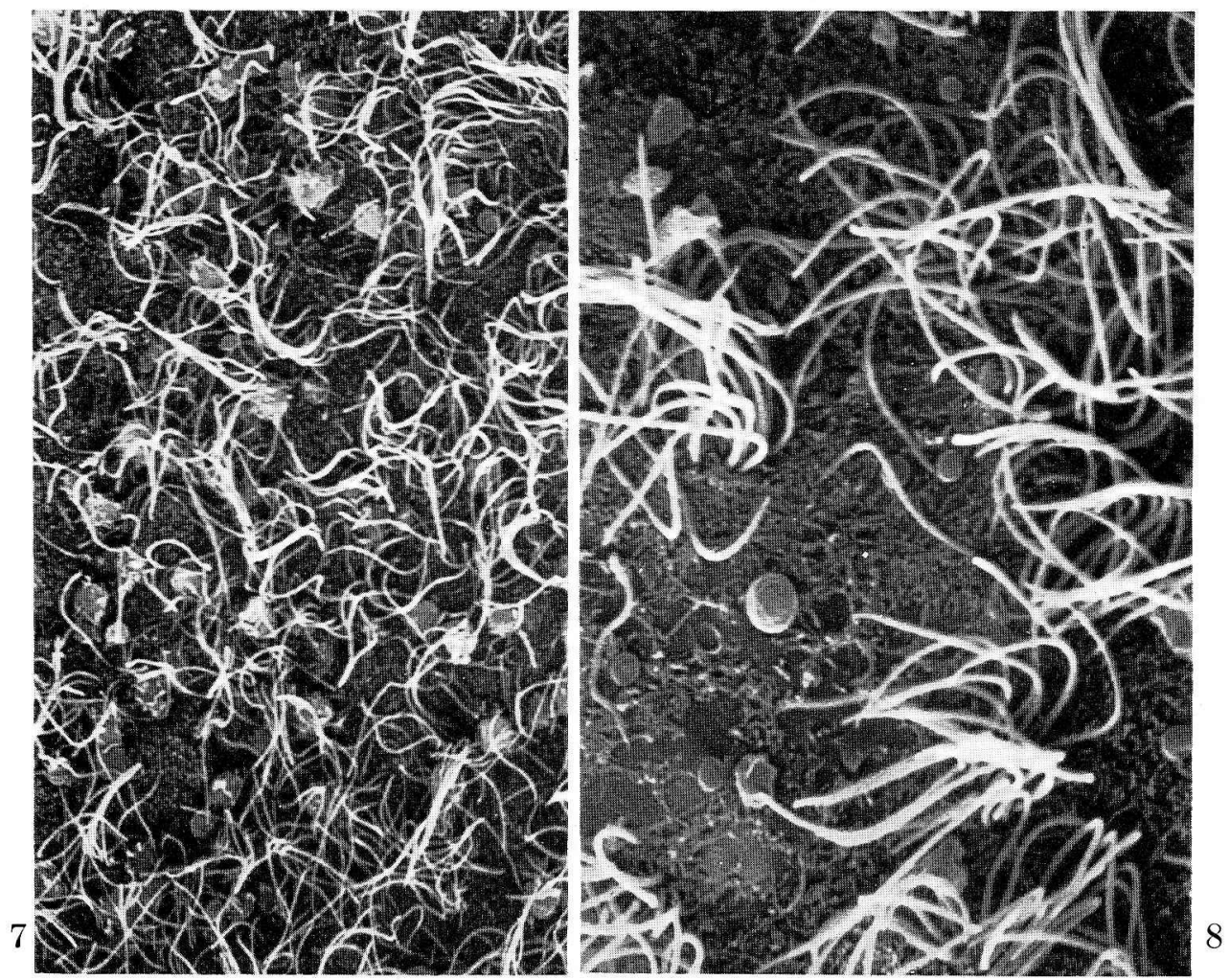

Fig. 7. Floor of the recessus infundibuli covered with the numerous microvilli, cilia and bulbous structures. $\times 2,000$

Fig. 8. Anterior portion of the ependymal layer of the recessus infundibuli. Note the bundle of cilia projecting from the ependymal cell into the ventricular cavity. $\quad \times 6,000$

measure from 1.5 to $2.0 \mu$ in diameter and are generally smooth in surface. A few bulbs may be equipped with minute projections (Fig. 5). If broken bulbs are observed, fine granules can be seen packed densely in the interior of the bulb. Besides the bulbs, granular and bleb-like protrusions are detected in the ependyma. Noticeably, in the ventral side of the lateral wall of the third ventricle, in particular the hypothalamic region, one may encounter a ridge bearing projections of an unknown nature consisting of spherical bodies of various sizes (Fig. 6). The spherical bodies in the surface measure 0.2 to $1 \mu$ in diameter. They seem to be referable to the Kolmer cell.

Fig. 4. Low power SEM view of the third ventricle near the commissurae postopticae to show the numerous cilia. $\times 2,000$

Fig. 5. Ventro-lateral wall of the ventricle equipped with the dense microvilli, numerous cilia and bulbous projections which are considered to be a part of so-called liquor-contacting neuron. Several bulbs with minute projections are seen in addition to the smooth surfaced ones. $\times 6,000$

Fig. 6. Another part of the ventro-lateral wall of the ventricle showing an unknown structure (probably Kolmer cell) consisting of numerous spherical bodies. $\times 6,000$ 
Recessus posteriosus: The ventricle of this region is also covered with microvilli and cilia, although these elements are fewer than in the ventral side of the lateral wall. The bulbous structures, essentially identical with those of the ventral side (Fig. 5), are protruded from the ependyma. They are almost smooth in surface; the minute projections are seldom recognized. The bulb is solid and occupied exclusively with fine granules.

Recessus infundibuli: The floor of the recessus infundibuli of the lamprey is considered to be homologous with the neurohypophysis in higher vertebrates, and the posterior half of the recessus infundibuli corresponds to their pars nervosa (neural lobe).

The anterior portion of the ependymal layer is equipped with innumerable microvilli, and the distribution of the cilia projected from the surface is comparatively dense. Moreover, numerous bulbous structures measuring about $1 \mu$ are seen. From an enlarged picture of the ependymal layer, it appears to be flat, and a bundle of cilia, 20 to 30 in number, projects from an ependymal cell into the ventricular cavity (Fig. 7).

On the other hand, the posterior portion of the ependymal layer is covered entirely with microvilli, and, characteristically, cilia are fewer than in the anterior portion (Fig. 8). The boundary of each ependymal cell is distinct, and its surface shows considerable undulation. A bundle of 15 cilia or thereabouts are protruded from each cell, bend and extend gradually toward the anterior tip of the bundle (Fig.

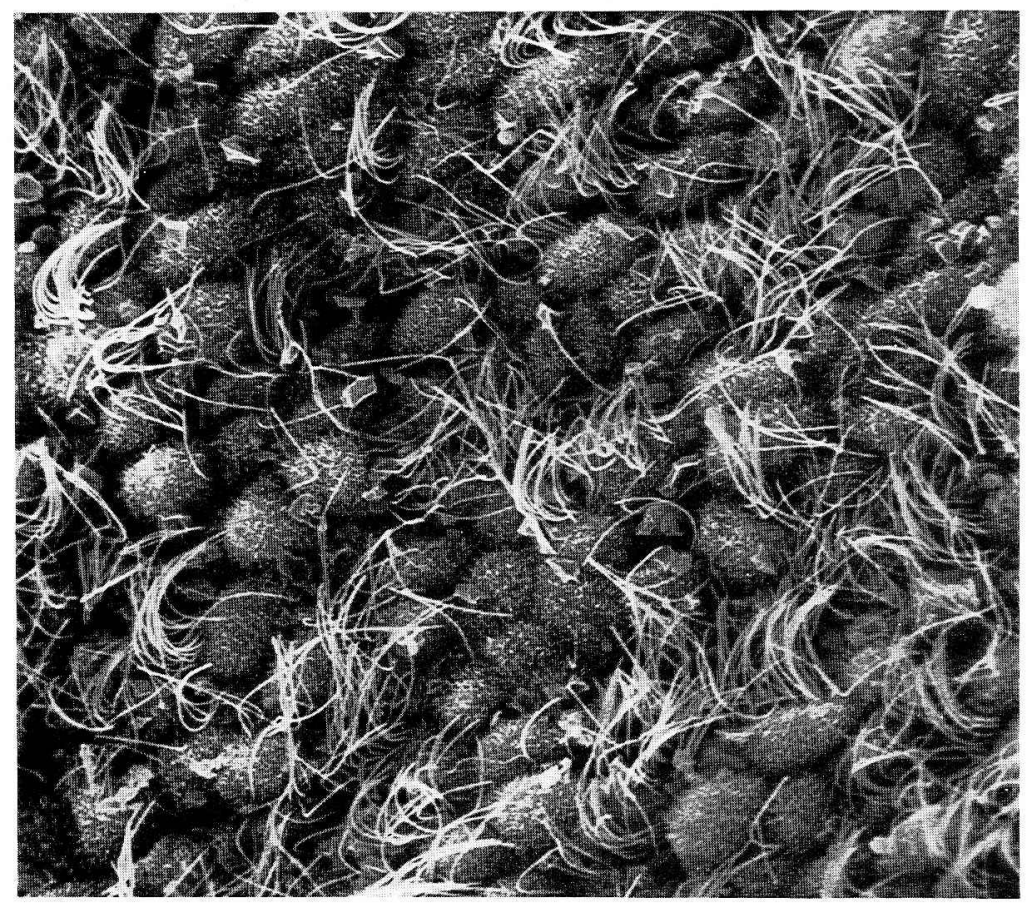

Fig. 9. Posterior portion of the ependymal layer of the recessus infundibuli covered entirely with the microvilli. The boundary of each ependymal cell (tanycyte) is clear and the bundle of cilia can be seen. $\times 2,000$ 
9). It is noticed that in the base of the ciliary bundle there is a spherule considered to be a secretory substance.

\section{Discussion}

By light microscopy and transmission electron microscopy, the liquor-contacting neurons have been recognized in the hypothalamic region near the ventricular wall of several vertebrate animals, such as carp (Cyprinus carpio), viviparid lizard (Lacerta viridis), rat, hedgehog and guinea pig (VIGH, 1971; VIGH-Teichmann, 1971; VIGH and Vigh-Teichmann, 1973). As scanning electron microscopy affords fine-structural examination over a wide surface, various ventricular structures among diverse vertebrates have been examined by these methods, including the wall of the third ventricle of the frog (Rana temporaria) (DE W AELE et al., 1974; DieRICKX and DE WAELE, $1975 \mathrm{a}, \mathrm{b}$ ), the organum vasculosum lamina terminalis (WEINDL and JoYNT, 1972), the floor of the third ventricle (CLEMENTI and Merini, 1972), and the recessus infundibuli (Scotr et al., 1972) of several mammalian species, such as the squirrel-monkey, cat and rabbit. However, a paper dealing with the third ventricle of the lamprey has not been available as yet.

Certain structures corresponding to the liquor-contacting neurons of higher vertebrates are seen in the ventral side of the lateral wall and the posterior portion of the recessus infundibuli in the lamprey (Fig. 5). By possessing the bulbous projections, the neurons in question are closely similar to the monoaminergic cells which are located in the subependyma of the lamprey and have been demonstrated histochemically by fluorescence microscope (Honma, 1969; Honma and Honma, 1970; Konst antinova, 1973; Ochi and Hosoy A, 1974). It seems reasonable enough to identify them as the same neurons.

The floor of the recessus infundibuli of the lamprey is equivalent to the neurohypophysis, and is roughly divided into two portions, anterior and posterior, the latter corresponding to the pars nervosa of the higher vertebrates (WINGSTRAND, 1966; Honma, 1969; Perks, 1969; Tsuneki et al., 1975). The pars nervosa borders on the pars intermedia with an intervening streak of capillary. So-called tanycytes and their allied cells proposed first by HorsTMANN (1954) in the brain of elasmobranchiate fish are also demonstrated in the present examination (Fig. 9). This type of ependymal cells has already been described in another lamprey (Lampetra fluviatilis) (PoLENov et al., 1974). The tanycytes have a bundle of cilia on their apex protruded into the ventricular cavity, while their long cytoplasmic projection is directed toward the outer (ventral) layer of the pars nervosa, and ends at a capillary wall. A spherule considered to be a secretory substance is noticed near the root of the ciliary bundle of the apex of the cell. Accordingly, the tanycytes of the lamprey neurohypophysis may have the possible role on the transportation of the substance, including secretion and absorption, between the cerebrospinal fluid and the capillaries of the systemic circulation as intimated by Polenov et al. (1974), and PeRCy et al. (1975). The present investigation reveals that there are some differences between the organization or structural pattern of the surface layer of the anterior neurohypophysis and the posterior one. However, whether or not an appreciable difference exists between the function of these two parts is unknown as yet. Moreover, the granular structures found in the ventral side of the lateral wall of the third ventricle likely corresponds to the 
Kolmer cells or the intraventricular macrophages (KoLmER, 1921; Hosoy a and Fujit A, 1973). However, their role and relation to the nearby structure are the problem remaining to be solved. Further scanning studies in combination with transmission electron microscopy on the third ventricular wall in several developmental stages of the lamprey are in progress to elucidate the organization and activities of its ependymal and subependymal layers.

\section{走査電子顕微鏡によるカワヤツメ第三脸室壁の観察}

塩田清二，本間義治，吉江紀夫，細谷安彦

遡河期のカワヤッメ (円口類) 学用い, 第三脳室壁とその周辺域の表面構造を, 走査電 子顕微鏡によって観察した。

側壁腹部，漏斗陥凹底および後方陷凹部它除く第三脳室壁の大部分は，上衣細胞のもつ 線毛によって完全におおわれている，側壁腹部它おおっている上衣層には，微絨毛や線毛 をそなえた多数の神経細胞の突出がみられる。この細胞は，いわゆる liquor-contacting neuron に相当するものと思われる. Tanycyte と同定される上衣細胞は，漏斗陥凹底の 後方部に認められる。この細胞の頂端には，多数の微絨毛と線毛束があり，基底の方は神 経性下垂体の外層に向かって突起岂伸ばし，腺性下垂体との間の毛細管壁に終末している. これらの線毛束の基部には，分泌物質様の小球体がみられた。後方陥凹部は，1層の上衣 細胞と, 脳室壁へ突起を出した神経細胞とからなる.

哺乳動物に観察された脳室内大食細胞とみなされる Kolmer 細胞と相同と思われるもの が,ヤッメウナギの脳室壁にもみられた.

\section{References}

Bertler, A., B. Falck and C. V. Mecklenburg: Monoaminergic mechanisms in special ependymal areas in Salmo irideus L. Gen. comp. Endocrinol. 3: 685-686 (1963).

Clementi, F. and D. Merini : The surface fine structure of the walls of cerebral ventricles and of choroid plexus in cat. Z. Zellforsch. 123: 82-95 (1972).

De Waele, G., K. Dierickx and N. Goosens : Scanning electron microscopy of the wall of the third ventricle of the brain of Rana temporaria. I. Scanning electron microscopy of the ventricular surface of the paraventricular organ. Cell Tiss. Res. 154: 511-518 (1974).

Dierickx, K. and G. De Waele: Ditto. II. Electron microscopy of the ventricular surface of the pars ventralis of the tuber cinereum. Cell Tiss. Res. 159: 81-90 (1975).

- Ditto. III. Electron microscopy of the ventricular surface of the median eminence. Cell Tiss. Res. 161: 343-349 (1975).

El Etreby, M. F., K. D. Richter and P. Günzel: Histological and histochemical differentiation of the glandular cells of the anterior pituitary in various experimental animals. Exc. Med. Int. Congr. Ser., no. 288, 14: 270-281 (1972).

Honma, S.: Presence of monoaminergic neurons in the spinal cord and intestine of the lamprey, Lampetra japonica. Arch. histol. jap. 32: 383-393 (1970). 
Honma, S. and Y. Honma: Histochemical demonstration of monoamines in the hypothalamus of the lampreys and ice-goby. Bull. Jap. Soc. Sci. Fish. 36: 125-134 (1970).

Honma, Y.: Some evolutionary aspects of the morphology and role of the adenohypophysis in fishes. Gunma Symp. Endocrinol. $6: 19-37$ (1969).

Horstmann, E. : Die Faserglia des Selachiergehirns. Z. Zellforsch. 39: 588-617 (1954).

Hosoya, Y. and T. Fujita: Scanning electron microscope observation of intraventricular macrophages (Kolmer cells) in the rat brain. Arch. histol. jap. 35: 133-140 (1973).

Kolmer, W.: Über eine eigenartige Beziehung von Wanderzellen zu den Chorioidealplexus des Gehirns der Wirbeltiere. Anat. Anz. 54: 15-19 (1921).

Konstantinova, M.: Monoamines in the liquor-contacting nerve cells in the hypothalamus of the lamprey, Lampetra fluviatilis L. Z. Zellforsch. 144: 549-557 (1973).

Murakami, T.: A revised tannin-osmium method for non-coated scanning electron microscopic specimens. Arch. histol. jap. 36: 183-193 (1974).

Ochi, J. and Y. Hosoya: Fluorescence microscopic differentiation of monoamines in the hypothalamus and spinal cord of the lamprey, using new filter system. Histochem. 40: 263-266 (1974).

Percy, R., J. F. Leatherland and F. W. Beamish: Structure and ultrastructure of the pituitary gland in the sea lamprey, Petromyzon marinus at different stages in its life cycle. Cell Tiss. Res. 157: 141-164 (1975).

Perks, A. M.: The neurohypophysis. In: (ed. by) W. S. Hoar and D. J. Randall: Fish physiology. vol. II, The endocrine system. New York and London, Academic Press, 1969.

Polenov, A. L., M. A. Belenky and M. S. Konstantinova : The hypothalamo-hypophysial system of the lamprey, Lampetra fluviatilis L. I. The neurohypophysis. Cell Tiss. Res. 150: 505519 (1974).

Scott, D. E., W. K. Paul and G. K. Dudley : A comparative scanning electron microscopic analysis of the human cerebral ventricular system. I. The third ventricle. Z. Zellforsch. 132: 203-215 (1972).

Tsuneki, K., H. Kobayashi, M. Yanagisawa and T. Bando: Histochemical distribution of monoamines in the hypothalamo-hypophysial region of the lamprey, Lampetra japonica. Cell Tiss. Res. 161: 25-32 (1975).

Vigh, B.: Das Paraventrikularorgan und das zirkumventrikuläre System des Gehirns. Stud. biol. hung. 10: 59-62 (1971).

Vigh, B., I. Teichmann und B. Aros : Das Paraventrikularorgan und das Liquorkontakt-Neuronensystem. Anat. Anz. Suppl. 125: 683-688 (1969).

Vigh, B. and I. Vigh-Teichmann : Comparative ultrastructure of CSF contacting neurons. Int. Rev. Cytol. 35: 189-251 (1973).

Vigh-Teichmann, I.: Vergleichende Untersuchungen der Beziehungen zwischen der hypothalamischen, periventrikulären grauen Substanz und dem Liquor cerebrospinalis. Cand. Med. Hung. Acad. Sci., Thesis, Budapest, 1971.

Vigh-Teichmann, I., B. Vigh and B. Aros: Ultrastructure of the CSF contacting neurons of the preoptic nucleus in the newt (Triturus cristatus). Acta morphol. Acad. Sci. hung. 18: 383394 (1970).

Weindl, A. and R. J. Joynt: Ultrastructure of ventricular walls. Three-dimensional study of regional specialization. Arch. Neurol. 26: 420-427 (1972).

Wingstrand, K. G.: Comparative anatomy and evolution of the hypophysis. In: (ed. by) G. W. Harris and B. T. Donovan: The pituitary gland. vol. I. London, Butterworts, 1966.

\author{
本間義治 \\ 干950-21 新潟市五十嵐 2 >町 \\ 新潟大学理学部 \\ 生物学教室
}

Dr. Yoshiharu Honma

Department of Biology

Faculty of Science, Niigata University

8050 Igarashi-2

Niigata, 950-21 Japan 